\title{
Does Capital Account Liberalization Affect the Financial Stability: Evidence from China
}

\author{
Yuanyuan Shen and Lu Yang*
}

\author{
School of Finance, Zhongnan Univerisity of Econoics and Law, Wuhan 430073, China
}

\begin{abstract}
This paper seeks to investigate the relationship between capital account liberalization and the financial stability in China. Furthermore, The Finite Distributed Lag Model is employed to quantify relationship between capital account liberalization and monetary crisis. And a general conclusion can be drawn that capital account liberalization is harmful to the stability official market in one year period, while the overall capital account liberalization effect can facilitate China's financial stability in a long run. Moreover, some suggestions are provided on China's capital account liberalization policies.
\end{abstract}

Keywords: Capital account liberalization, Financial risk, Financial stability, Finite Distributed Lag Model.

\section{INTRODUCTION}

As China promotes The Silk Road Economic Belt and the 21st Century Maritime Silk Road abroad and establishes the Asian Infrastructure Investment Bank, a policy choice has also been widely discussed about when it is wise to open capital account completely.

Capital account liberalization is defined as freedom from prohibitions on transactions in the capital and financial accounts of the balance of payments (Eichengreen and Mussa, 1998). Capital account reflects changes in ownership of national asset and debt in the balance of payments, including capital transfers, foreign direct investment, portfolio investment, and capital flows into bank account or provided as loans. (Foreign Exchange Management Regulation of People's Republic of China, 2008)

In recent years, along with the completion of the process of setting cross-border trade account in RMB, signing bilateral currency swap agreements with 28 countries, and RMB being listed as reserve currency in more than 30 countries. The government in China is gradually promoting a situation where large-scale capital structure flows freely. Additionally, cross-border capital flows have also become an inevitable trend.

According to the neoclassical theory, liberalizing capital account can contribute to the efficiency of international allocation of capital. The flow of capital flows from the capital-abundant countries to the developing countries for a higher return of the capital. Furthermore, developing countries can also reduce

*Address correspondence to this author at the School of Finance, Zhongnan Univerisity of Econoics and Law, Wuhan 430073, China;

Tel: +8615979181734; Fax: +862788386770; E-mail: kudeyang@znufe.edu.cn, kudeyang@gmail.com

JEL: G12,G2 their cost of capital, enhancing the welfare all over the world.

To be specific, given that China is a capital-scarce country, liberalizing capital account will attract a large amount of international financial institutions to provide financial services. Therefore, competitive pressure from foreign peers will force the domestic financial institutions continuously improve their types and qualities of financial products and enhance their operating efficiency. Therefore, it can greatly improve their competitive capacity.

However, the potential financial risk arisen from increasing frequent flows of capital can never be ignored. Since the 1990s, a number of world financial crises broke out and become more and more serious which undeniably blame in part on a large international capital. To be specific, when risk-management techniques in a country are underdeveloped or significant financial market distortions exist, capital account liberalization is likely to bring about some attacks on the economic and financial stability in a country (Eichengreen and Mussa, 1998). The 1994 Mexican exchange rate crisis and the 1997 Asian financial crisis can be compelling evidences to prove it. If the economic and financial conditions reach a developed stage, and a nation rushes to open capital account, it is quite likely to result in serious currency crisis. Given the high rate of return in China, once capital account liberalization begins, the amount of international capital inflows are expected to surge, including a large amount of foreign direct investment and international hot money. And excessive capital inflows are likely to cause bubble economy in China, causing unnecessary fluctuation of economy. Once disturbances happen, it may induce a reversal move of capital, resulting in panic flight of capital in a short time. This outward capital flows can shake Chinese 
residences' confidence in the domestic banking system, and thus affect the stability of the financial system.

In spite of negative effects of capital account liberalization on the stability of financial market we mentioned above, Goldstein (1999) found a casual relationship between them, and found out that the openness of capital account does not necessarily lead to the outbreak of the financial crisis. In view of the fact that China is going through a crucial period of liberalizing capital account, it is our best interest to find out the correlation between the openness of capital account and potential financial risks.

This article focuses on the empirical analysis on the correlation between capital account liberalization and financial risk by applying finite distributed lag model which can take time lag into consideration. Further, this paper addresses following questions: (1) How long does capital account openness have influence on the stability of financial market? (2) Is the overall influence of capital account liberalization on stability of financial market positive or negative?

The rest of this paper proceeds as follows. Section 2 reviews the literature on the correlation between capital account liberalization and the financial stability. Section 3 gives the definition and quantitative approach of variables. Section 4 uses Finite Distributed Lag Model to estimate the equation and provides empirical results. Section 5 concludes.

\section{LITERATURE REVIEW}

At the beginning of the capital account liberalization in Mexico, a number of studies, both in theory and in practice, have analyzed the correlation between capital account liberalization and economy growth.

In the neoclassical theory, resources flow from capital-abundant developed countries, where the return to capital is low, to capital-scarce developing countries where the return to capital is high. The flow of resources into the developing countries reduces their cost of capital, triggering a temporary increase in investment and growth that permanently raises their standard of living (Obstfeld, 1995). Therefore, this can optimize the allocation of resources.

As the cost of capital account convertibility gradually captured economists attention, Bakker and Chapple (2002) provided the evidence claiming that removal of controls on capital flows could strengthen downward pressure on the exchange rate, caused domestic running out of domestic market, led to tax evasion and resulted in depletion of foreign exchange reserves. Furthermore, it could even damage national monetary policy independence to some extent.

Other evidences are found out that the financial risk of capital flows did not necessarily evolve into a currency crisis or a banking crisis, which depends primarily on national monetary authorities' policy and international economic environment facing. For example, authors like Goldstein (1999) claimed that the Asian crisis, and by implication emerging-market financial problems in general, should be blamed on the incompatibility of underdeveloped domestic financial markets with an open capital account. Eichengreen and Leblang (2003) documented that capital account liberalization net effect on the stability of economy was context specific based on a panel of historical data for 21 countries covering the period 1880-1997. The benefits are likely to dominate its costs when the domestic financial system is robust and the international financial system is not prone to costly and disruptive crises. Furman, Stiglitz, Bosworth and Radelet (1998) blamed the Asian crisis on vulnerabilities created by the operation of the international financial system. Therefore, it is quite essential to set up a series of policy on the financial system before entire capital account is open.

Henry Peter (2006) found out that date of stock market liberalization in Mexico was 1989, which was five years prior to the Mexican crisis of December 1994. Nevertheless, Henry (2006) did not make empirical analysis on the causal link between the onset of stock market liberalizations and the rash of subsequent emerging-market financial crises. Therefore, when trying to determine whether liberalizations or fundamentals cause crises, it is important to think critically about timing.

In a word, precious studies focus on the nexus between capital account liberalization and economy growth. And such ink has been spilled over the theoretical analysis on the relationship between capital account liberalization and financial risk, while the empirical analysis still remains relatively uncharted territory, especially those taking time lag into consideration. Compared to existing literature, our major contribution is that we put time lag into our model and quantitatively analyze the relationship between capital liberalization and the financial stability. 


\section{DATA}

In this section, this paper explains the methodology of quantitative analysis on the relationship of capital account liberalization and financial comprehensive indexes to estimate two variables, that is, the degree of capital account liberalization and the financial stability. Then, this paper model the basic estimated equation, which is used to test the correlation between two variables.

\section{a. The Indicator of the Degree of Financial Risk Exchange Market Pressure Index}

To quantify the degree of financial risk, this paper uses exchange market pressure index as the indicator to test the degree of financial risks.

Exchange market pressure index (EMP), which is also known as the currency crisis stress index, is a comprehensive index which is used to measure relative changes in interest rates, exchange rates and reserves. According to Contagious currency crises written by Eichengreen et al. (1996), the currency crisis is an excess pressure which the monetary authority can accommodate by running down their international reserves or by raising interest rate, or which will be shown as the currency depreciation. Therefore, we establish as EMP a weighted average of nominal interest rates changes, exchange rates changes and reserves changes. This definition not only covers the exchange rate depreciation when the currency crisis occurred, but also considers the loss of reserve which monetary authorities take to prevent the currency depreciation and the increase of interest rate, and is also considered as the most comprehensive definition which take all significant variables related to the currency crisis into consideration.

According to Contagious currency crises written by Eichengreen et al. (1996), exchange market pressure can be defined as the following equation:

$$
E M P_{i}=\lambda_{R E R} \frac{\Delta R E R_{\mathrm{t}}}{R E R_{t-1}}+\lambda_{R I R} \frac{\Delta R I R_{\mathrm{t}}}{R E R_{t-1}}+\lambda_{F E R} \frac{\Delta F E R_{\mathrm{t}}}{F E R_{t-1}}
$$

where $E M P_{\mathrm{t}}$ is exchange market pressure measure as relative changes in the real exchange rate $\triangle R E R_{\mathrm{t}}$, the real interest rate $\triangle R I R_{\mathrm{t}}$ and foreign exchange reserves $\triangle F E R_{\mathrm{t}}$. Further, $\triangle R E R_{\mathrm{t}}, \triangle R I R_{\mathrm{t}}$ and $\triangle F E R_{\mathrm{t}}$ are yearly gaps of the real exchange rate, the real interest rate and the foreign exchange reserve; $\lambda_{R E R}, \lambda_{R I R}$ and $\lambda_{F E R}$ is the weight of each components.
Obviously, the benefit of using an unweighted average is simplicity. However, given that the volatility of reserves, exchange rates and interest differential is quite different, it is quite essential to prevent any one of them from dominating the index. Therefore, to make sure that the conditional variance of three components in this equation can be equal, we weight them as following equation:

$$
\lambda_{i}=\left(\frac{1}{S_{D t D e v}}\right) /\left(\frac{1}{S_{t D e v_{R E R}}}+\frac{1}{\operatorname{StDev}_{\text {RIR }}}+\frac{1}{\operatorname{StDev}_{F E R}}\right)
$$

Where StDev $_{R E R}$ StDev ${ }_{\text {RIR }}$ and StDev ${ }_{F E R}$ are standard deviations of real exchange rate changes, real interest rate changes and foreign exchange reserve changes.

Empirical attempts build on the IMF database which covers the data from 1983 to 2013, and also use the real interest rate data from the World Bank database.

Therefore, we calculate the standard variances and weights of each components as following:

Table 1: Descriptive Statistics

\begin{tabular}{|c|c|c|c|}
\hline & Exchange rate & Interest rate & Reserve \\
\hline \hline $\begin{array}{l}\text { Standard } \\
\text { variance }\end{array}$ & 37.4089 & 2.3005 & 1167.4086 \\
\hline Weight & 0.0267 & 0.4347 & 0.00086 \\
\hline
\end{tabular}

\section{b. The Definition of Capital Account Liberalization}

Since removing restrictions on capital account will directly lead to an increasing mobility of capital flows, therefore we can use the scale of capital flows to indirectly estimate the extent of capital account openness. Therefore, we use the ration of the sum of capital inflows $(\mathrm{Cl})$ and capital outflows (CO) to GDP as a measure of capital account liberalization indicators in Eq. (3). According to Edison et al. (2004), this definition reflects the long-term trends in capital markets, which covers changes in capital account liberalization in a longer period.

$L B=\frac{(C I+C O)}{G D P}$

The dataset is based on the China National Bureau of Statistics database. We select the data of debit capital and financial account (Unit: USD million), credit capital and financial account (Unit: USD million) and gross national product (Unit: USD million). 


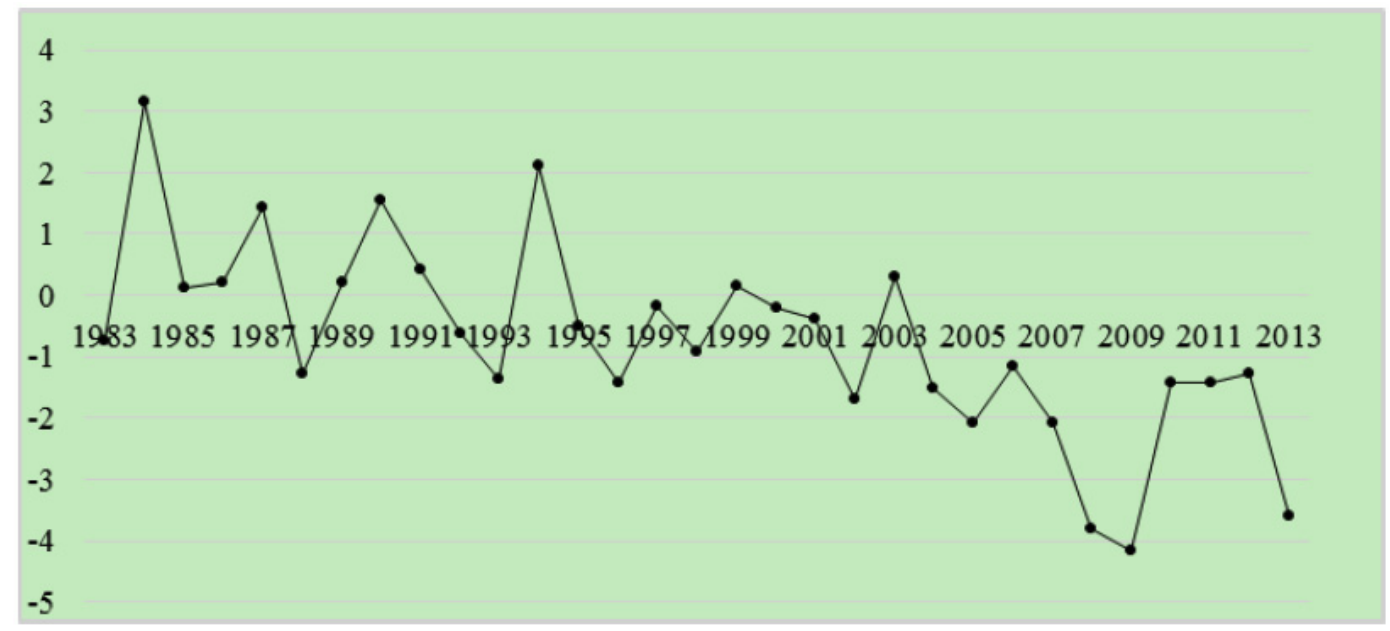

Figure 1: Currency Crisis pressure index.

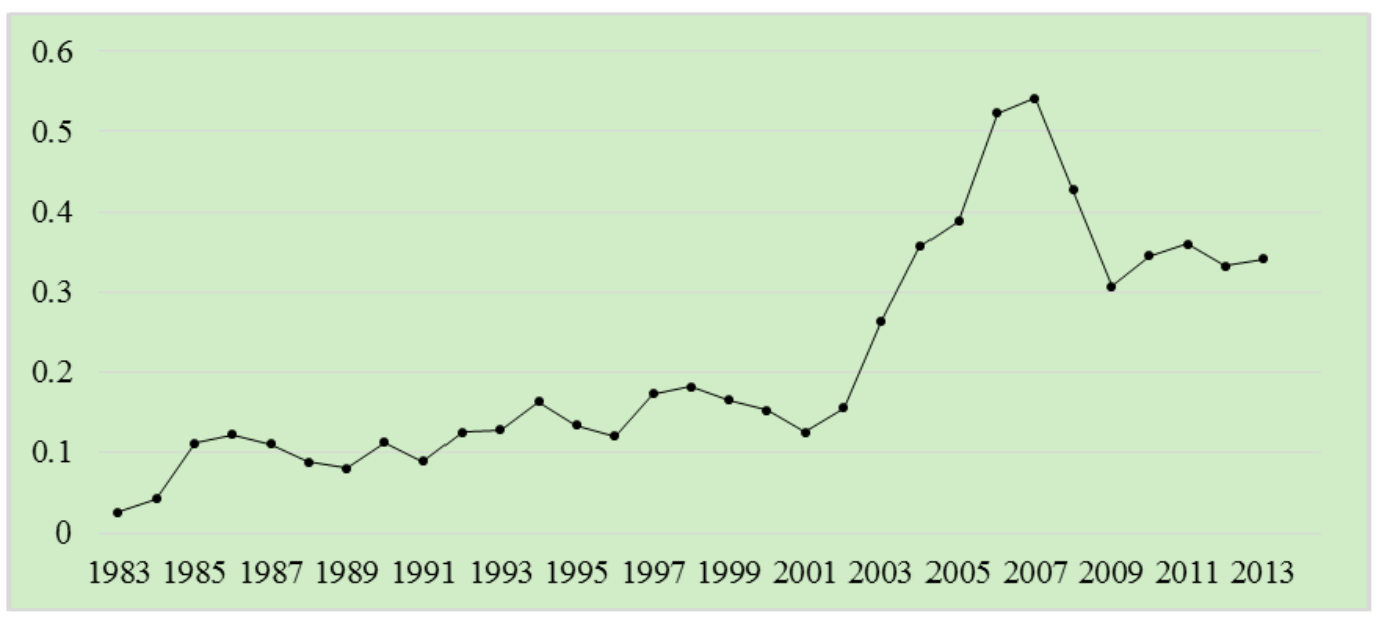

Figure 2: The extent of capital account liberalization.

Figure 2 reflects the result of the degree of capital account liberalization from 1983 to 2013. In general, we can see a upward curve of the degree of capital account liberalization from 1983 to 2013, which is consistent with the fact that the monetary circumstance in China have the cyclicality of capital account liberalization, and each cycle of capital account openness is higher than the previous one. This finding shows an inevitable trends to promote capital mobility. In addition, as we can see in Figure 2, the openness of capital account in China gradually went up from 1983 to 1994 , which may post some negative effect on the financial stability, and thus the Asian Financial Crisis broke out, causing a gigantic attack on the foreign exchange market in China, especially in Hong Kong. Taking the time lag into consideration, this correlation will be tested in the next section.

However, as China's economy gradually recovered since 2001, China was pushing forward several measures to promote the process of lifting capital controls for the following years. For example, in December 2002, China enacted the Qualified Foreign Institutional Investor (QFII) system, which allowed foreign institutional investors to invest in domestic securities market. Since April 2006, the Qualified Domestic Institutional Investor (QDII) system has been implemented. foreign direct investment basically convertible, foreign direct investment to achieve some convertible, banks, brokers, funds and insurance asset management companies have launched QDII funds. These measures leaded to an increasing mobility of capital flows. In 2007, the degree of capital account liberalization reached the peak before the outbreak of the subprime financial crisis in 2008. And with strengthened control on capital flows in the period immediately following subprime financial crises in 2008 which mitigated the impact of large-scale outward capital flows, the stability of financial market was under protection. And in the next two years, the economic 
situation continues to improve, and the capital account liberalization continues to move into the process of deregulation.

\section{EMPIRICAL RESULTS}

After liberalizing capital account, more frequent flows of capital can affect a country's financial stability through multiple pathways. And sudden capital flows can cause serious macroeconomic consequences, even financial crises through foreign exchange market, and this influence of capital account liberalization on the financial stability exhibits time lag. Therefore, the analysis of correlation between capital

In this context, taking this long period impact into account, this article will establish FDLM (Finite Distributed Lag Model) (Cromwell, 1994) to empirically analyze the relationship between the degree of capital account openness and the financial stability.

\section{a. Specifications of Model}

In this section, this paper try to find out that is capital account liberalization correlated with financial crises, even after taking into account the effects of current and lagged liberalizing capital account influences. We analyze yearly macroeconomic data of China which is discussed in the section 6 from 1983 through 2013.

In this context, this article estimate the following equation:

$$
E M P_{t}=\alpha+\beta_{0} L B_{t}+\beta_{1} L B_{t-1}+\beta_{2} L B_{t-2}+\cdots+\mu_{\mathrm{t}}
$$

Where the dependent variable is $E M P_{\mathrm{t}}$, which is Exchange Market Pressure Index; $L B_{t-i}$ is the degree of capital account liberalization of i year; $\alpha$ is the fixedeffect, and $\mu_{\mathrm{t}}$ is the disturbance term.

\section{b. Test for Stationary Time Series}

In this part, we use ADF test (Dickey and Fuller, 1979), one of the most common method of unit root test for stationary test, to test time series data. The result are shown in Table 2. In Table 2, we can see that the time series data of exchange market pressure index is stationary, and while that of the degree of capital account liberalization is nonstationary, the first difference is stationary, which means that it is integrated of order one. Therefore, regression analysis can be performed.
Table 2: Test for Unit Root and Causality

\begin{tabular}{|c|c|c|}
\hline & EMP & LB \\
\hline \hline ADF test & $-4.819^{* * *}$ & $-3.75407^{* * *}$ \\
\hline Granger causality test & $4.247^{* *}$ & $9.542^{* * *}$ \\
\hline
\end{tabular}

Notes: Null hypothesis for EMP is EMP does not Granger Cause LB while null hypothesis for LB is LB does not Granger Cause EMP.

denotes significant at $1 \%$ level.

denotes significant at $5 \%$ level.

\section{c. The Granger Causality Test (Granger, 1969)}

As Table 2 shows, probability of the original hypothesis that the degree of capital account liberalization is not the reason EMP is 0.0009 , and is less than the significance level of $5 \%$. Therefore it proves the correlation of the capital account openness and the exchange market pressure.

\section{d. Empirical Findings}

The regression procedure was implemented according to Eq.(4), and the result is shown as following:

$$
\begin{aligned}
& E M P_{\mathrm{t}}=0.7693+1.6168 L B_{t}-2.6601 L B_{t-1}-6.9370 L B_{t-2}+\mu_{t} \\
& S_{\mathrm{e}}=(0.3507)(2.1498)(0.4603)(2.1013) \\
& t=(2.1935)(0.7521)(-5.7791)(-3.3012)
\end{aligned}
$$

$R=0.6003 S_{e}=0.9700 p=0.000007$

The model result shows that the time delay of capital account liberalization influence on the stability of financial market is two years. And a one-year shortterm multiplier effect of the degree of capital account liberalization is positive, which is 1.6168 , while the long term multiplier effect of that is negative, which is 7.9803. This result shows that capital account openness poses some threat on the foreign exchange market at the very beginning, which brings some financial pressures or add risk to financial market. However, capital account liberalization can facilitate the China's financial stability in a long run. This result is correlated with the reality of China. Capital account liberalization is bound to bring an increasing amount of capital flows and result in foreign exchange market instability, which may be prone to produce financial crisis. The results are similar to the studies of Henry (2006). However, in the long term, in order to make benefits of capital flows dominated, numerous financial policies, such as relative foreign exchange system 


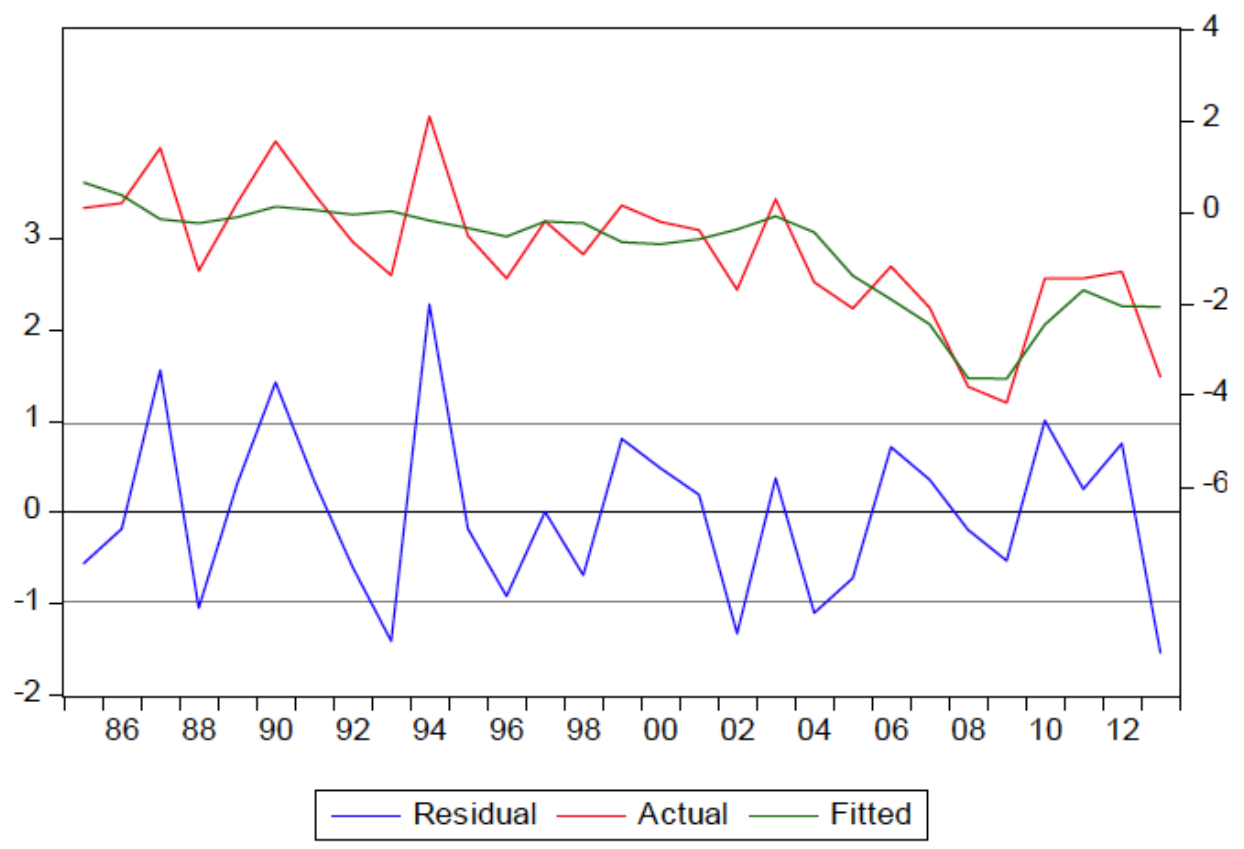

Figure 3: The actual exchange market pressure index, model fitting exchange market pressure index movements and error.

reform, interest rate reform and other reform measures, have also been pushed forward, which constantly optimize our financial environment. Therefore, along with the process of capital account liberalization, the financial environment has been improved and the financial stability in China has been reinforced.

\section{CONCLUSTION}

This paper discusses how long the capital account liberalization influences on the financial stability in China, and examines whether the overall impact on the financial stability is positive or negative. Using yearly data of real exchange rate, real interest rate, foreign reserve and inflow and outflow of capital, two significant comprehensive factors were established, which are exchange market pressure index and the degree of capital account liberalization, to quantitative analysis their relationship.

Taking time lag into consideration, this paper employs the Finite Distributed Lag Model to test the correlation. And it is evident that capital account liberalization is firstly harmful to the stability official market in one year period, while the overall capital account liberalization effect can facilitate the China's financial stability in a long run. And this influence can last two year at $5 \%$ significance level. Therefore, the promotion of capital account liberalization should not be rejected, even if it may cause some negative influences at the very beginning.

\section{Policy Implication}

First, monetary authority in should speed up the process of exchange rate reform to realize a managed floating exchange rate system. Since free flows of capital can closely link between domestic currency and foreign currencies, it is quite indispensable to establish a more reasonable exchange rate formation mechanism which can truly reflect accurate price signals and rational price expectations.

Second, to mitigate the influences of large-scaled sudden capital inflows, Chinese government should speed up the process of economic restructuring and promote the balance of payments.

Third, Chinese government should pay much attention to the development of foreign exchange market, and enable it to better fulfill its role in price discovery, resource allocation and financial risk prevention. Additionally, more implements in foreign exchange market should be innovated so as to further promote the diversification of investment strategy and reduce the systematical risk. In part of Chinese monetary authority, it is indispensable to maintain a prudent investment attitude and promote investment model.

\section{ACKNOWLEDGEMENT}

We are grateful to an anonymous referee and the associate editor for their helpful comments and 
suggestions. The research was supported by the Fundamental Research Funds for the Central Universities (Grant Number, 105/31541410516).

\section{REFERENCES}

Bakker, A., \& Chapple, M. B. (2002). Advanced country experiences with capital account liberalization. International Monetary Fund, working paper series, No. 214. http://dx.doi.org/10.5089/9781589061170.084

Cromwell, Jeff B. et al. (1994). Multivariate Tests For Time Series Models. SAGE Publications.

Dickey, D. A.; Fuller, W. A. (1979). "Distribution of the Estimators for Autoregressive Time Series with a Unit Root". Journal of the American Statistical Association 74 (366): 427-431. http://dx.doi.org/10.2307/2286348

Eichengreen, B., \& Leblang, D. (2003). Capital account liberalization and growth: was Mr. Mahathir right? International Journal of Finance \& Economics, 8(3), 205-224. http://dx.doi.org/10.1002/ijfe.208
Eichengreen, B., Rose, A. K., \& Wyplosz, C. (1996). Contagious currency crises. National Bureau of Economic Research. working paper series, No. w568.

Furman, J., Stiglitz, J. E., Bosworth, B. P., \& Radelet, S. (1998). Economic crises: evidence and insights from East Asia. Brookings papers on economic activity, 1-135. http://dx.doi.org/10.2307/2534693

Goldstein, M. (1999). The Asian financial crisis: Causes, cures, and systemic implications (Vol. 55). Thunderbird International Business Review, 41(6), 721-728.

Granger, C. W. J. (1969). "Investigating Causal Relations by Econometric Models and Cross-spectral Methods". Econometrica 37 (3): 424-438. http://dx.doi.org/10.2307/1912791

Hali Edison, Michael Klein, Luca Ricci and Torsten Slok (2004). "Capital Account Liberalization and Economic Performance: Survey and Synthesis". IMF Staff Papers, vol. 51, 2.

Henry, P. B. (2006). Capital account liberalization: Theory, evidence, and speculation. National Bureau of Economic Research, working paper series, No. w12698.

Obstfeld, M. (1995). The logic of currency crises. Springer Berlin Heidelberg.

(c) 2015 Shen and Yang; Licensee Lifescience Global.

This is an open access article licensed under the terms of the Creative Commons Attribution Non-Commercial License (http://creativecommons.org/licenses/by-nc/3.0/) which permits unrestricted, non-commercial use, distribution and reproduction in any medium, provided the work is properly cited. 